\title{
STUDI GAYA: STILISTIKA DUA PUISI KEPENYAIRAN SUMATERA UTARA SEBAGAI BAHAN AJAR PADA MATA KULIAH APRESIASI PUISI
}

\author{
Mhd. Anggie Januarsyah Daulay, Mhd. Surif, Ita Khairani. \\ Prodi Sastra Indonesia FBS Unimed Medan-Sumatera Utara \\ 081370069751
}

anggie.fbsunimed@yahoo.com, surif@unimed.ac.id, Itakhairanie@ rocketmail.com

\begin{abstract}
Abstrak
Penelitian ini bertujuan untuk mengungkap deskripsi gaya (style) struktur teks pada dua puisi Kepenyairan Sumatera Utara terhimpun pada buku Antologi Puisi Seribu Sajak Tao Toba. Indikator penelitian yang digunakan berpedoman pada empat aspek gaya (style) berdasarkan studi Stilistika Sastra meliputi, a) gaya diksi, b) gaya rima, c) gaya citraan, dan d) gaya bahasa figuratif. Pencapaian hasil analisis pada penelitian ini, menerapkan jenis penelitian kualitatif dengan menggunakan metode deskriptif, yakni mendeskripsikan data melalui analisis gaya dua puisi penyair Sumatera Utara dalam kajian Stilistika Sastra. Hasil penelitian, disimpulkan sebagai berikut, (1) Sebuah Kenangan Ziarah ke Atas Danau karya Paulus Simangunsong terdapat dua jenis gaya diksi yaitu denotasi dan konotasi, gaya rima rima patah dan terus, gaya citraan penglihatan, perasaan, pengecapan, penciuman, dan gerak, serta gaya bahasa figuratif retoris, ekskalamasio, personifikasi, alegori, dan hiperbola. (2) Tao Toba karya Evi Sihite terdapat gaya diksi denotasi dan konotasi, gaya rima yang rima sejajar, gaya citraan penglihatan dan citraan perasaan, serta gaya bahasa figuratif antiklimaks, sarkasme, ekskalamasio, dan polisidenton. Luaran yang telah dicapai adalah buku bahan ajar ber-ISBN, publikasi ilmiah dalam jurnal nasional, prosiding seminar internasional, dan integrasi hasil penelitian pada RPS mata kuliah Apresiasi Puisi.
\end{abstract}

\section{Kata kunci: Stilistika Sastra, dua puisi Kepenyairan Sumatera Utara}

\section{A. Pendahuluan}

Perspektif sastra melihat Stilistika sebagai suatu kajian yang menyelidiki gaya (style) kebahasaan sastrawan melalui karyanya. Kekuatan sebuah karya sastra dapat dikatakan terletak pada kemampuan menciptakan kombinasi baru, bukan objek baru. Dalam hal ini, jenis sastra puisilah yang dianggap sangat cocok sebagai objek kajian stilistika. Puisi memiliki medium yang terbatas yang hanya terdiri dari beberapa baris kalimat, tetapi harus mampu menyampaikan pesan sama dengan cerpen bahkan novel yang terdiri dari beberapa halaman (Ratna, 2009: 16). Genre sastra puisi tidak terlepas dari kehadiran seorang penyair sebagai pusat perasaan, pemikiran, dan pemaknaan. Setiap penyair memiliki perasaan, pemikiran, dan pemaknaan yang berbeda-beda, hal inilah yang menjadi salah satu ciri khas gaya kepenyairan dari seorang sastrawan. Salah satu upaya yang dapat dilakukan untuk melihat gaya kepenyairan adalah melalui pengkajian secara komprehensif terhadap teks sastra tersebut. 
Seperti halnya seorang Chairil Anwar; memiliki kekhasan gaya kepenyairannya yang meledak-ledak dan bertemakan kritik sosial, sastrawan-sastrawan di Sumatera Utara juga tentu memiliki gaya kepenyairan yang unik dan menarik untuk diungkap, karena pada hakikatnya melalui manifestasi gaya dalam karya tersebut, ideologi penyair akan terlihat. Beberapa sastrawan Sumatera Utara yang karya puisinya akan dianalisis adalah Sebuah Kenangan Ziarah ke Atas Danau karya Paulus Simangunsong dan Tao Toba karya Evi Sihite. Dua puisi karya beberapa penyair di atas termakhtub dalam buku Antologi Puisi Seribu Sajak Tao Toba yang dipublikasikan oleh penerbit CV. Mitra Medan pada tahun 2014 dan digagas oleh Jhon Fawer Siahaan, seorang penyair kelahiran Sumatera Utara yang aktif pada teater Opera Batak, pengurus Komunitas Jendela Toba, sekaligus sebagai praktisi pada Plot (Pusat Latihan Opera Batak).

Selanjutnya, hasil penelitian ini, diarahkan pada pembuatan bahan ajar mata kuliah Apresiasi Puisi kepada mahasiswa. Apresiasi puisi merupakan mata kuliah yang fokus mengkaji dan menelaah puisi dari berbagai perspektif analisis. Kajian stilistika dirasa tepat digunakan untuk membedah gaya kebahasaan pada puisi-puisi tersebut, sehingga akan menambah khazanah keilmuan mahasiswa terhadap kecirikhasan para sastrawan dalam menghasilkan karya-karyanya. Berdasarkan uraian tersebut, formulasi pertanyaan yang tepat digunakan dalam penelitian ini adalah bagaimana gaya kepenyairan pada struktur teks tiga puisi sastrawan Sumatera Utara dalam antologi puisi Seribu Sajak Tao Toba ditinjau dari aspek Stilistika sastra puisi, yakni : a) gaya pemilihan kata (diksi); b) gaya rima; c) gaya citraan; dan d) gaya bahasa figuratif (permajasan).

\section{B. Kajian Teori}

Pada karya seni sastra, dikenal istilah dulce dan utile. Hal ini berkaitan dengan fungsi sastra dalam kehidupan. Kata (dulce) mengandung arti sastra yang baik adalah sastra yang manis, memberikan kesenangan, dan menghibur, sedangkan (utile) berarti memberikan suatu manfaat. Antara kedua fungsi sastra ini, saling melengkapi. Kesenangan pada konteks fungsi sastra ini, tidak sama dengan kesenangan yang didapat dari karya non-sastra. Kesenangan di sini lebih tinggi hakikatnya, kontemplasi yang tidak mencari keuntungan. Sedangkan manfaatnya berupa keseriusan penanaman estetik bahasa dan pengolahan persepsi pembaca. Dengan pemahaman ini, pengalaman hidup disaring, dijernihkan, dan dikristalkan sehingga pembaca menarik kesimpulan dari berbagai kekayaan pengalaman, perasaan, pengamatan, ide, gagasan, yang ditawarkan sastrawan dalam suatu karya. 
Sejalan dengan pendapat di atas, Daulay (2013: 62) berpendapat, stilistika memliki manfaat yang luas, diantaranya, a) Mengidentifikasi dan menemukan fakta dari setiap keestetikaan karya sastra, b) Mengidentifikasi letak ciri kekhassan secara luas pada masingmasing sastrawan yang terlihat jelas pada perbedaan karya, c) Menjadi sumber pengetahuan akan perbedaan bahasa, dinamika gaya, dan letupan imajiner seorang sastrawan, d) Dalam proses telaahannya, menjadi nilai tersendiri dari penelaah tentang aktivitas alam liar sastrawan yang meliputi gejolak psikosis dan bentuk rasa, e) Mengemukakan pada massa dalam bentuk makalah sastra tentang korelasi yang tersusun baik antara penggunaan bahasa dalam karya sastra, f) Membantu dunia kesusastraan untuk segera memperbaiki problematika karya dengan peningkatkan mutu menjadi lebih baik, g) Menjadikan hubungan yang harmonis antara penelaah dengan kegiatan penelaahan selanjutnya.

Keilmiahan analisis sastra terletak pada objektifitas wacana yang ditelaah dengan cara menampilkan hasil laporan penggunaan style (konteks stilistika) para sastrawan sejujur dan seadilnya, tanpa berniat untuk menghakimi cara berbahasa mereka melalui pemaparan gaya (style). Pada penelitian ini, indikator analisis yang digunakan adalah a) pemilihan kata (diksi), b) rima, c) citraan, dan d) bahasa figuratif. Hal ini didasarkan kepada objek analisis berupa teks tulisan puisi yang tidak dilisankan (dibacakan), sehingga keempat indikator ini cocok digunakan untuk mengetahui gambaran gaya pada puisi-puisi sastrawan. tersebut.

\section{Metode Penelitian}

Metode yang digunakan adalah metode deskriptif yakni mendeskripsikan data melalui analisis gaya dua puisi penyair Sumatera Utara dalam kajian Stilistika Sastra. Adapun aspek gaya dalam kajian tersebut adalah gaya diksi, gaya rima, gaya citraan, dan gaya bahasa figuratif. Dengan metode deskriptif, maka hasil penelitian yang diperoleh melalui proses identifikasi dan analisis data dideskripsikan secara objektif. Metode pengumpulan data yang paling tepat adalah metode simak. Metode simak merupakan metode yang digunakan dalam penelitian bahasa dengan cara menyimak penggunaan bahasa pada objek yang diteliti (Sudaryanto, 2003:132). Langkah-langkah metode simak yang akan dilaksanakan adalah 1) menyimak data secara intensif dan berulang-ulang; 2) melakukan penyeleksian data; 3) mencatat data-data yang dinilai relevan; 4) melakukan analisis data sesuai dengan teori yang digunakan; dan 5) menyusun laporan penelitian. 


\section{Hasil dan Pembahasan}

\section{Hasil Penelitian}

a. Puisi Sebuah Kenangan Ziarah ke Atas Danau Karya Paulus Simangunsong

\section{1) Gaya Diksi}

\begin{tabular}{|c|l|l|}
\hline No & \multicolumn{1}{|c|}{ Diksi Denotasi } & \multicolumn{1}{|c|}{ Diksi Konotasi } \\
\hline 1 & ah, sampai juga aku di kaki bukit ini & $\begin{array}{l}\text { bak seonggok permata di tengah bumi } \\
\text { Sumatera }\end{array}$ \\
\hline 2 & uff.. Berubah & $\begin{array}{l}\text { Danau tawar maha luas } \\
\text { Permukaan tenang }\end{array}$ \\
& $\begin{array}{l}\text { Dulu, tidak terngah-ngah seperti ini } \\
\text { Perut pun belum sebesar ini } \\
\text { Umur memang tidak bisa dibohongi }\end{array}$ & \begin{tabular}{l} 
Berkilauan di terpa raja siang \\
\hline
\end{tabular} \\
\hline
\end{tabular}

\section{2) Gaya Rima}

\begin{tabular}{|c|c|c|}
\hline No & Rima Patah & Rima Terus \\
\hline 1 & $\begin{array}{c}\text { Huff..berubah. } \\
\text { Dulu, tidak terngah-engah seperti ini. } \\
\text { Perut pun belum sebesar ini. } \\
\text { Umur memang tidak bias dibohongi. }\end{array}$ & $\begin{array}{l}\text { Aku masih ingat pelajaran dari guruku. } \\
\text { Sekolah dasar di tepi danau,menghadap } \\
\text { danau. } \\
\text { Tiap saat, bila perlu. }\end{array}$ \\
\hline & & Kami bebas menatap danau \\
\hline
\end{tabular}

\section{3) Gaya Citraan (Imaji)}

\begin{tabular}{|c|l|l|l|l|l|}
\hline No & \multicolumn{1}{|c|}{$\begin{array}{c}\text { Citraan } \\
\text { Penglihatan }\end{array}$} & $\begin{array}{c}\text { Citraan } \\
\text { Perasaan }\end{array}$ & $\begin{array}{c}\text { Citraan } \\
\text { Pengecapan }\end{array}$ & $\begin{array}{c}\text { Citraan } \\
\text { Penciuman }\end{array}$ & \multicolumn{1}{c|}{$\begin{array}{c}\text { Citraan } \\
\text { Gerak }\end{array}$} \\
\hline 1 & $\begin{array}{l}\text { Itukah hutan } \\
\text { keramba yang } \\
\text { sekarang mengisi } \\
\text { danau? }\end{array}$ & $\begin{array}{l}\text { Amangoi } \\
\text { amang, loja } \\
\text { kali pun. }\end{array}$ & $\begin{array}{l}\text { dan ikan-ikan } \\
\text { taw yang } \\
\text { lezat }\end{array}$ & $\begin{array}{l}\text { Tidak ada bau } \\
\text { kol busuk } \\
\text { seperti ini }\end{array}$ & $\begin{array}{l}\text { Hanya } \\
\text { sampan- } \\
\text { sampan kecil } \\
\text { mondar- } \\
\text { mandir }\end{array}$ \\
\hline 2 & $\begin{array}{l}\text { Kujamin, } \\
\text { siapapunpastiter } \\
\text { pana }\end{array}$ & $\begin{array}{l}\text { Dihembus } \\
\text { angin } \\
\text { sungguh } \\
\text { sejuk }\end{array}$ & $\begin{array}{l}\text { Di sini ada } \\
\text { taman } \\
\text { haramonting. }\end{array}$ & - & $\begin{array}{l}\text { Dan anak- } \\
\text { anak perang- } \\
\text { perangan di } \\
\text { tengah } \\
\text { pandang }\end{array}$ \\
\hline 3 & $\begin{array}{l}\text { Memukau mata } \\
\text { dan hati }\end{array}$ & $\begin{array}{l}\text { Tenang. } \\
\text { Segar }\end{array}$ & $\begin{array}{l}\text { Makan sambil } \\
\text { menatap danau } \\
\text { di ujung sana }\end{array}$ & - & - \\
\hline 4 & $\begin{array}{l}\text { Kami bebas } \\
\text { menatap danau }\end{array}$ & - & - & - & - \\
\hline 5 & $\begin{array}{l}\text { Tiga puluh tahun } \\
\text { kupandang } \\
\text { kajahnya dari } \\
\text { kaki bukit ini }\end{array}$ & - & - & - & - \\
\hline
\end{tabular}

\section{4) Gaya Bahasa Figuratif (Pemajasan}

\begin{tabular}{|c|l|l|}
\hline No & Bahasa Figuratif & \multicolumn{1}{c|}{ Kutipan } \\
\hline 1 & Retoris & itukah hutan keramba yang sekarang mengisi danau? \\
\hline 2 & Ekskalamasio & $\begin{array}{l}\text { Astaga! } \\
\text { Itukah hutan keramba yang sekarang mengisi danau? } \\
\end{array}$ \\
& & Deretan keramba yang dituliskan di berit. \\
\hline
\end{tabular}




\begin{tabular}{|c|l|l|}
\hline \multirow{5}{*}{} & \multirow{2}{*}{} & Siapa yang punya? \\
& & Tak lagi seperti dulu. \\
\cline { 3 - 3 } & & Mempesona! \\
& & Tak heran bila penghuni pulau, \\
& & Dan sepanjang tepi danau \\
& & Tiada habis menoreh puji-puji lewat lagu \\
& & Yang tergubah begitu saja namun merdu \\
\cline { 3 - 3 } & & $\begin{array}{l}\text { Sekolah setinggi mungkin } \\
\text { Setinggi mungki! }\end{array}$ \\
\hline 3 & Personifikasi & $\begin{array}{l}\text { Bukit-bukit menjulang tinggi mengitari danau, } \\
\text { Mengukir puluhan tanjung dan teluk }\end{array}$ \\
\hline 4 & Alegori & bak seenggok permata di tengah bumi Sumatera \\
\hline 5 & Hiperbola & Beratus ribu manusia \\
\hline
\end{tabular}

\section{b. Puisi Tao Toba Karya Evi Sihite}

\section{1) Gaya Diksi}

\begin{tabular}{|c|l|l|}
\hline No & \multicolumn{1}{|c|}{ Diksi Denotasi } & \multicolumn{1}{c|}{ Diksi Konotasi } \\
\hline 1 & $\begin{array}{l}\text { lihat.. Kau adalah air kehidupan dan juga } \\
\text { obat bagi mereka yang sakit }\end{array}$ & ingat kau adalah permata \\
\hline 2 & lupakan sajak ini. Tapi ingat pesannya & $\begin{array}{l}\text { sedikit saja kau bergetar dunia sudah } \\
\text { takut }\end{array}$ \\
\hline
\end{tabular}

\section{2) Gaya Rima}

\begin{tabular}{|c|c|}
\hline No & Rima Sejajar \\
\hline 1 & Generasimu jangan tumpul hatinya \\
& generasimu bukan penjilat \\
generasimu bukan konsumen & generasimu adalah creator \\
& anak-anak gadismu bukan pembantu budak arab dan Malaysia \\
buka mata dan hatimu. \\
\\
anak-gadismu bertenun, bertanam tanaman, \\
hidup dari keringat tangannya \\
itulah anak gadismu, boruni rajamu \\
generasimu punya prinsip! \\
generasimu punya harga diri. \\
\\
kamu punya semua kekayaan yang kami butuhkan \\
percikkan kami kasih \\
percikkan kami toleransi \\
percikkan kami budaya yang kuat
\end{tabular}

\section{3) Gaya Citraan (Imaji)}

\begin{tabular}{|c|l|l|}
\hline No & \multicolumn{1}{|c|}{ Citraan Penglihatan } & \multicolumn{1}{c|}{ Citraan Perasaan } \\
\hline 1 & Lihat, kau adalah air kehidupan & $\begin{array}{l}\text { Menambat hati bagi dunia dan selalu } \\
\text { ingin kembali untukmu }\end{array}$ \\
\hline 2 & Percikkan keindahanmu & hey toba buka hati kami \\
\hline
\end{tabular}

\section{4) Gaya Bahasa Figuratif (Pemajasan)}

\begin{tabular}{|c|l|c|}
\hline No & Bahasa Figuratif & Kutipan \\
\hline 1 & Antiklimaks & Generasi mu jangan tumpul hatinya \\
\hline
\end{tabular}




\begin{tabular}{|c|l|l|}
\hline & & $\begin{array}{l}\text { Generasi mu bukan penjilat } \\
\text { Generasi mu bukan konsumen } \\
\text { Generasimu adalah } \text { creator }\end{array}$ \\
\hline 2 & Sarkasme & $\begin{array}{l}\text { anak anak gadis mu bukan pembantu budak arab dan } \\
\text { Malaysia }\end{array}$ \\
\hline 3 & Ekskalamasio & generasimu punya prinsip! \\
\hline 4 & Polisidenton & lupakan sajak ini. Tapi ingat pesannya \\
\hline
\end{tabular}

\section{Pembahasan}

\section{a. Puisi Sebuah Kenangan Ziarah ke Atas Danau Karya Paulus Simangunsong 1) Gaya Diksi}

Diksi yang diungkapkan dalam puisi Sebuah Kenangan Ziarah ke Atas Danau, merupakan diksi yang mengandung makna denotatif yaitu makna sebenarnya atau makna yang memang sesuai dengan pengertian yang dikandung oleh kata tersebut. Terlihat dari awal puisi penulis menggunakan kata yang mengandung makna sebenarnya

"Ah, sampai juga aku di kaki bukit ini”.

Potongan puisi di atas masuk kedalam makna denotasi karena menggunakan bahasa yang mudah di pahami dan merupakan makna sebenarnya dari kalimat tersebut. Dari awal kalimat penyair menggunakan kata "Ah" yang menandakan sebuah kepuasan karena sudah sampai di bukit yang telah lama tokoh aku tinggalkan. Tidak hanya itu pada bait ke dua pada puisi “sebuah kenangan ziarah ke atas danau” juga termasuk kedalam makna denotasi.

Huff.. berubah.

Dulu, tidak terngah-engah seperti ini.

Perut pun belum sebesar ini.

Umur memng tidak bisa dibohongi

Kutipan puisi di atas menggunakan bahasa sehari-hari sehingga mudah di pahami maka masuk kedalam makna kata denotasi yang merupakan makna sebenarnya. Pada potongan larik puisi diatas penulis menyatakan bahwa dulu sewaktu masih muda tidak seperti ini, perut belum sebesar ini, dan sekarang sudah berubah, perut menjadi besar, nafas terengah-engah saat mendaki ke bukit yang ada di atas Danau Toba, terlihat sekali sudah tua tokoh aku yang ada pada puisi tersebut. Diksi yang mengandung makna konotatif yaitu bukan makna sebenarnya. Dengan kata lain, makna kias atau makna tambahan. Dalam puisi "Sebuah Kenangan Ziarah Ke Atas Danau” juga banyak menggunakan makna kias, salah satunya terlihat pada potongan bait puisi berikut bait puisi.

\section{"Bak seonggok permata di tengah bumi Sumatera"}

Kutipan puisi di atas penyair menyampaikan bahwa Danau Toba merupakan sebuah keindahan alam yang terletak di provinsi Sumatera, terdapat kata kias pada kutipan di atas 
kutipan yang dimaksud adalah kata "seonggok". Penyair juga mengatakan bahwasannya Danau Toba merupakan sebuah harta yang sangat berharga di Sumatera, penyair menganalogikannya dengan kata "permata" Tidak hanya itu ada kutipan lain yang termasuk dalam makna konotasi, terlihat pada kutipan berikut

\section{Danau tawar maha luas, \\ Permukaan tenang, \\ Berkilauan diterpa raja siang,}

Ketiga kutipan di atas penyair menggunakan makna kias yang menyatakan bahwa Danau Toba ialah danau yang sangat luas, permukaan danau yang tenang tidak berombak, bahkan berkilauan saat di terpa matahari, makna kias tersebut disematkan untuk menggantikan kata lain, makna kias yang dimaksud adalah “raja siang” yang berarti matahari.

\section{2) Gaya Rima}

Unsur rima yang digunakan penyair dalam puisi Sebuah Kenangan Ziarah ke Atas Danau ialah Rima Patah (ABBB). Ada beberapa bait dalam puisi ini yang menggunakan rima patah. Contoh potongan puisi yang menggunakan rima patah terlihat pada kutipan berikut,

\section{Huff.. berubah.}

Dulu, tidak terngah-engah seperti ini.

Perut pun belum sebesar ini.

Umur memng tidak bisa dibohongi.

Pada bait puisi di atas penulis menggunakan rima patah terlihat pada akhiran dari setiap baris terdapat beberapa akhiran yang sama seperti (i-i-i) namun ada satu akhiran yang berbeda yaitu (h) sehingga dapat disebut rima patah. Terdapat rima patah pada bait puisi diatas merupakan cara penyair membawakan imajinasi pembaca. Bahwa pada saat itu penyair sudah berusia senja sehingga faktor usia mempengaruhi staminanya. Selanjutnya pada puisi "Sebuah kenangan ziarah ke atas danau" terdapat rima terus yaitu pengulangan vokal yang sama terdapat pada akhir larik sebuah sajak. Terlihat dari kutipan larik puisi berikut

Aku masih ingat pelajaran dari guruku. Sekolah dasar di tepi danau, menghadap danau.

Tiap saat, bila perlu, Kami bebas menatap danau

Pada kutipan di atas dapat dilihat bahwa penyair menggunakan rima terus yaitu rima dengan pengulangan vokal yang sama terlihat pada akhir larik puisi yang serupa yaitu (a-a-a-a). Penyair menggunakan rima terus bertujuan untuk menggambarkan masa lalunya yang bersekolah di tepi danau dengan segala kenangan manis. 


\section{3) Gaya Citraan}

Puisi Sebuah Kenangan Ziarah Ke Atas Danau Karya Paulus Simangunsong secara umum menceritakan tentang kenangan ziarah ke danau toba. Terdapat beberapa citraan yang tersirat dalam bait-baitnya, terlihat pada kutipan berikut.

\section{Ah, sampai juga aku di kaki bukit ini. \\ Amangoi amang, loja kali pun. \\ Sudah tiga puluh tahun, tidak terasa. \\ Sesudah tiga puluh tahun, \\ Akhirnya kembali lagi kesini. \\ Tiga puluh tahun. \\ Cepat sekali waktu berlalu.}

Pada bait pertama, ditemukan citraan perasaan yang terdapat pada larik Amangoi amang, loja kali pun, larik ini mempunyai makna perasaan yang sudah lelah akibat sesuatu hal. Citraan perasaan yang dimaksud dapat tergambar dari kata loja yang bermakna lelah. Ketujuh larik puisi diatas penyair menggambarkan tokoh aku yang sudah tiga puluh tahun meninggalkan desa yang terletak tidak jauh dari Danau Toba, karena tokoh aku seseorang yang sudah lanjut usia sehingga penyair menggambarkan kelelahan tokoh aku saat mendaki bukit yang ada di desa tersebut.

Astaga!

\section{Itukah hutan keramba yang sekarang mengisi danau? \\ Deretan keramba yang dituliskan di berita.}

Siapa yang punya?

Selanjutnya kutipan di atas yang berkategori citraan penglihatan terlihat pada bait keenam, Itukah hutan keramba yang sekarang mengisi danau?, dalam larik tersebut, penyair mengambarkan penglihatan seseorang terhadap hutan keramba yang menghiasi danau. Penyair juga memberi kesan heran terhadap kondisi danau yang dilihatnya, mungkin dulu sebelum tokoh aku meninggalkan desa tersebut belum ada hutan keramba di bibir danau.

Tak lagi seperti dulu.

Dahulu,

\section{Hanya sampan-sampan kecil mondar-mandir \\ Diatas air bening \\ Dahulu. Ya, dahulu.}

Selanjutnya citraan gerak dapat terlihat pada bait ketujuh yaitu pada larik Hanya sampan-sampan kecil mondar-mandir. Larik ini menunjukkan sebuah gerakan sampan di atas air danau yang dituangkan oleh penyair melalui kata mondar-mandir, dimana umumnya mondar-mandir dikatakan untuk menggambarkan seorang yang sedang bergerak ke tempat 
yang satu ketempat lain secara berulang. Kutipan larik puisi tersebut ungkapan tokoh aku mengenai keadaan Danau Toba sebelum ia tinggalkan.

\section{Kalau sempat menyaksikannya dulu,}

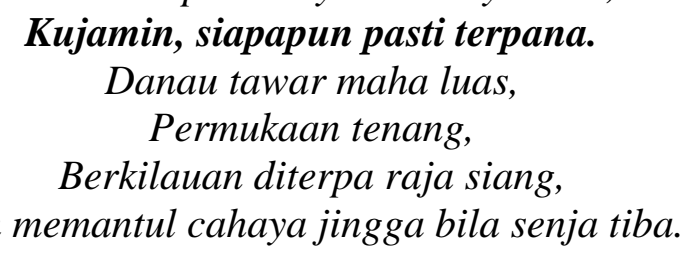

Pada bait kedelapan, citraan penglihatan kembali dihadirkan penyair pada puisi tersebut. Kujamin, siapapun pasti terpana, kata terpana menunjukkan adanya sesuatu yang dilihat oleh mata. Bait puisi di atas penjelasan selanjutnya dari tokoh aku yang telah mengetahui keindahan Danau Toba yang luas dan indah sebelum hutan keramba menghiasi bibir danau.

\section{Bukit-bukit menjulang tinggi mengitari danau, Mengukir puluhan tanjung dan teluk,}

\section{Memukau mata dan hati.}

Dulu.

Citraan penglihatan juga terlihat pada baik kesepuluh yang terdapat pada larik Memukau mata dan hati. Larik ini menunjukkan sesuatu yang memukau mata. Hal ini dituangkan penyair dalam kata memukau. Keempat baris puisi di atas merupakan cara penyair menggambarkan melalui citra penglihatan mengenai Danau Toba yang dikelilingi bukit-bukit hijau asri membuat ribuan bola mata terpana.

Di tengah danau, daratan Samosir membentang Tempat rumah adat, gereja, kuburan, sawah, dan lading.

Dan anak-anak perang-perangan di tengah pandang

Citraan gerak terlihat pada baik kesebelas. Dan anak-anak perang-perangan di tengah pandang, di mana kata perang-perangan yang dimaksud menunjukkan adanya gerakan yang dilakukan oleh anak-anak yang tinggal di sekitaran Danau Toba.

Aku masih ingat pelajaran dari guruku. Sekolah dasar di tepi danau, menghadap danau.

Tiap saat, bila perlu,

\section{Kami bebas menatap danau}

Kutipan di atas menggambarkan citraan penglihatan yang terlihat pada bait ketiga belas. Kami bebas menatap danau. Kesan yang tersebut menggambarkan adanya pemandangan danau yang dituangkan oleh penyair. Penyair menuliskan kisah tokoh aku saat masih sekolah dasar 
yang tidak jauh dari Danau Toba sehingga menjadi objek utama di kesehariannya. Citraan pengecapan terdapat pada puisi ini, yakni hadir pada bait kelima belas. Berikut kutipannya,

Sejak dahulu kala pula ia memberi sumber kehidupan

Bagi orang-orang yang berdiam di sekitarnya

Air bersih yang bening, dan ikan-ikan tawar yang lezat

Kata lezat dalam larik tersebut menunjukkan indera pengecap yang digambarkan oleh penyair. Dari ketiga baris puisi penyair memberikan gambaran kehidupan manusia yang hidup di sekitaran danau. Sejak dulu Danau Toba sudah membantu masyarakat setempat dengan hasil produksi danau tersebut. Bukit-bukit yang berada tepat disekeliling danau juga menghasilkan air bersih untuk berbagai keperluan.

Tak terasa,

Sudah tiga puluh tahun kutinggalkan danau ini, Tiga puluh tahun tak kupandang wajahnya dari kaki bukit ini

Selanjutnya pada bait kesembilan belas terdapat citraan penglihatan yakni pada larik Tiga puluh tahun tak kupandang wajahnya dari kaki bukit ini. Larik ini menunjukkan citraan penglihatan yaitu pada kata kupandang. Pada bait puisi di atas tokoh aku sudah lama tidak melihat Danau Toba dari salah satu bukit yang ada di keliling danau.

\section{Diberangkatkan dari dermaga danau}

\section{Dihembus angin sungguh sejuk.}

Kutipan pada bait kedua puluh satu di atas menggambarkan citraan perasaan. Citraan perasaaan yang dimaksud terdapat dalam larik Dihembus angin sungguh sejuk. Larik ini menunjukkan sebuah kebahagiaan tersendiri yang dituangkan oleh penyair pada puisinya. Bagian ini penyair menggambarkan suhu saat berada di Danau Toba, sungguh sejuk kata tokoh aku.

Masa kecil aku sering main ke sini.

Kalau di surge ad ataman Eden,

Di sini ada taman haramonting,

Surga makanan untuk anak-anak di umurku.

Selanjutnya citraan pengecapan hadir pada bait ke ketiga puluh satu seperti yang terlihat pada kutipan di atas. Kata haramonting merupakan makanan yang dapat dikonsumsi oleh anak-anak di Danau Toba. Bait di atas tokoh aku menggambarkan Danau Toba adalah surga sewaktu ia kecil karena ada banyak makanan di dalam hutan di tepi danau. 


\section{Aku dan teman-teman biasa bermain ke sini, \\ Memetik haramonting lalu duduk di batu ini, \\ Makan sambil menatap danau di ujung sana, \\ Tenang. Segar. \\ Tidak ada bau kol busuk seperti ini. \\ Jangan Tanya lagi kenapa!}

Pada bait ketiga puluh tiga di atas, ditemukan pula citraan pengecapan yaitu pada larik Makan sambil menatap danau di ujung sana. Kata makan pada larik tersebut merupakan pengimajian yang dituangkan penyair lewat citraan pengecap. Selanjutnya citraan perasaan juga terdapat dalam bait puisi di atas yaitu pada larik Tenang. Segar. kata tenang dan segar menunjukkan perasaan yang tentram. Citraan selanjutnya adalah citraan penciuman yaitu terdapat pada larik Tidak ada bau kol busuk seperti ini, kata bau pada larik tersebut menunjukkan indera penciuman terhadap bau kol. Dari ketiga kutipan puisi di atas memiliki tiga unsur citraan yang berbeda penyair menyampaikan kesan bahwa tidak hanya Danau Toba yang tercemar tetapi hutan yang ada di bukit-bukit pinggiran danau juga ikut tercemar akibat ulah manusia-manusia yang tidak bertanggung jawab.

\section{4) Gaya Bahasa Figuratif (Majas)}

Berikut adalah analisi Bahasa Figuratif (Majas) pada Puisi Sebuah Kenangan Ziarah Ke Atas Danau Karya Paulus Simangunsong. Majas Retoris adalah ungkapan pertanyaan yang jawabannya telah terkandung di dalam pertanyaan tersebut, terdapat pada larik itukah hutan keramba yang sekarang mengisi danau?. Kutipan tersebut mengungkapkan sebuah pertanyaan penulis, yang di dalamnya sudah terdapat jawabannya. Terlihat dari kalimat itukah yang mengartikan, penulis sudah melihat hutan keramba sehingga pertanyaan tersebut tidak membutuhkan jawaban. Selanjutya terdapat majas ekskalamasio yang merupakan ungkapan dengan menggunakan kata-kata seru. Terlihat pada kutipan berikut ini.

\section{Astaga! \\ Itukah hutan keramba yang sekarang mengisi danau? \\ Deretan keramba yang dituliskan di berita. \\ Siapa yang punya? \\ Tak lagi seperti dulu.}

Pada kutipan di atas, terdapat awal kata yang mengungkapkan semua penegasan untuk kalimat-kalimat selanjutnya. Di sini terlihat bagaimana penulis mencoba mengungkapkan rasa terkejut melihat yang ada di sekitar Danau Toba sudah tak indah seperti dulu, sekarang banyak keramba-keramba yang merusak pandangan dn juga membuat air danau tercemar. Selain itu Majas ekskalamasio juga ditemukan pada kutipan berikut. 


\section{Mempesona! \\ Tak heran bila penghuni pulau, \\ Dan sepanjang tepi danau \\ Tiada habis menoreh puji-puji lewat lagu \\ Yang tergubah begitu saja namun merdu}

Kutipan di atas, juga terdapat kata awal yang mengungkapkan penegasan ditandai dengan kalimat seru, yang mana menggambarkan perasaan penyair begitu terpukau dengan keadaan Danau Toba yang dulu. Selain itu pengambaran menggunakan kalimat seru juga terdapat dalam bait di bawah ini.

\section{Sekolah setinggi mungkin \\ Setinggi mungkin!}

Kutipan di atas juga merupakan majas ekskalamasio karena mengungkap penegasan penulis yang dulunya merasakan sekolah hingga kejenjang yang lebih tinggi dan meninggalkan Danau Toba untuk waktu yang lama. Selanjutnya terdapat majas personifikasi. Majas personifikasi adalah gaya bahasa yang seakan menggantikan fungsi benda mati yang dapat bersikap layaknya manusia. Terlihat pada kutipan berikut ini.

\section{Bukit-bukit menjulang tinggi mengitari danau, Mengukir puluhan tanjung dan teluk}

Kutipan di atas masuk dalam majas personifikasi karena, penyair menggambar bukitbukit yang kenyataannya tidak bisa bergerak, namun seolah-olah bukit tersebut dapat mengitari dan mengukir yang merupakan kata kerja dalam kehidupan manusia, sehingga dapat dikatakan bait ini menggunakan majas personifikasi. Bait tersebut penyair menggambarkan banyak bukitbukit di sekeliling Danau Toba, yang menambah keindahan pesona alam Sumatera.

Selanjutnya terdapat pula majas Alegori yang merupakan majas menyatakan dengan sesuatu dengan cara lain, melalui kiasaan atau penggambaran, terdapat pada larik bak seenggok permata di tengah bumi Sumatera. Pada larik tersebut, penulis mencoba mengumpamakan keindahan Danau Toba seperti layaknya permata yang indah dan berharga yang letak nya di tengah pulau Sumatera. Selanjutnya majas Hiperbola yaitu majas yang mengungkapkan sesuatu dengan kesan berlebihan. Pada larik Beratus ribu manusia tersebut sudah menggunakan kata "beratus" lalu ditambah lagi dengan kata "ribu" yang membuat kesan berlebihan pada potongan puisi tersebut. 


\title{
b. Puisi Tao Toba Karya Evi Sihite
}

\section{1) Gaya Diksi}

Pada puisi Tao Toba karya Evi Sihite penulis banyak menggunakan diksi yang menggunakan makna denotatif yang merupakan makna yang sebenarnya dari suatu kata atau kalimat. Diksi pada puisi tersebut terlihat pada larik lihat.. kau adalah air kehidupan dan juga obat bagi mereka yang sakit. Larik puisi ini memaparkan pesan dengan bahasa yang mudah dipahami tentang Danau Toba sebagai sumber kehidupan penduduk sekitar.

Selanjutnya pada larik lupakan sajak ini. Tapi ingat pesannya larik puisi bait terakhir penyair menjelaskan bahwa yang harus dilihat pada puisi ini adalah pesannya, yaitu Danau Toba merupakan identitas penduduk Sumatera Utara. Pesan yang disampaikan penyair masih terus terjaga sampai saat ini namun itu hanyalah sebatas identitas, membanggakan keindahan danau, tetapi untuk melestarikannya tidak dilakukan. Diksi yang digunakan mengandung makna konotasi yaitu bukan makna sebenarnya, makna kias atau makna tambahan. Puisi Tao Toba terlihat pada bait pertama Ingat.. kau adalah permata penulis mengutarakan bahwasanya danau toba bagaikan sebuah permata, yang dimaksud penulis dari kata permata ialah Danau Toba adalah harta yang berharga karena Danau Toba merupakan satu-satunya harta dari Sumatera yang dijuluki dengan danau terbesar di Indonesia.

Selanjutnya makna konotasi terdapat juga terdapat pada larik Sedikit saja kau bergetar dunia sudah takut. Melalui larik tersebut penyair, memaparkan tentang bahayanya jika Gunung Toba meletus, akan membuat banyak orang ketakutan. Kenyataannya dahulu Gunung Toba pernah meletus sebanyak tiga kali yang menyebabkan penyusutan populasi di belahan bumi saat itu, hal ini sesuai dengan data yang di paparkan pada halaman wikipedia.

\section{2) Gaya Rima}

Rima adalah perulangan bunyi yang sama dalam puisi yang berguna untuk menambah keindahan suatu puisi. Puisi Tao Toba menggunakan Rima Sejajar yang bermakna apabila sepatah kata dipakai berulang-ulang dalam kalimat yang beruntun, berikut kutipan yang menggambarkan rima sejajar. Berikut kutipannya.

\author{
generasi mu jangan tumpul hatinya \\ generasi mu bukan penjilat \\ generasi mu bukan konsumen \\ generasi mu adalah creator \\ anak anak gadis mu bukan pembantu budak arab dan Malaysia \\ buka mata dan hati mu. \\ anak gadis mu bertenun, bertanam tanaman, \\ hidup dari keringat tangan nya \\ itulah anak gadismu mu, boru ni raja mu
}




\author{
generasi mu punya prinsip! \\ generasimu punya harga diri. \\ kamu punya semua kekayaan yang kami butuhkan \\ percikkan kami kasih \\ percikkan kami toleransi \\ percikkan kami budaya yang kuat
}

Pada kutipan di atas, rima sejajar yang sepatah kata dipakai berulang-ulang dalam kalimat yang beruntun, terlihat pada kata generasi mu diulang pada baris berikutnya, lalu kata anak gadis yang diulang kembali pada baris berikutnya, serta kata percikan kami yang diulang kembali pada baris berikutnya, pengulangan kata tersebut yang menggambarkan rima sejajar. Penyair menggunakan rima sejajar pada kutipan larik puisi diatas bertujuan sebagai kalimat penegasan.

\title{
3) Gaya Citraan
}

Puisi Tao Toba karya Evi Sihite ini menceritakan tentang pesan untuk Danau Toba dan mejadikannya sebagai salah satu kekayaan bangsa. Pada puisi ini terdapat dua citraan yang dituangkan penyair, yakni citraan penglihatan dan perasaan. Citraan penglihatan terlihat pada kutipan berikut.

Ingat..kau adalah permata

lihat.. kau adalah air kehidupan dan juga obat bagi mereka yang sakit menambat hati bagi dunia dan selalu ingin kembali untuk mu

ledakan gunung merapi mu mengguncang dunia, ice age dan kelaparan ingat kau punya martabar di seluruh asia dan dunia

kami tergantung kepada mu

kamu identitas kami

tanah leluhur nenek moyang kami

jika tanah nenek moyang dan identitas kami di rampas

apakah kami ini berarti? Kami akan menjadi di perbudak penguasa

bangkers, mental kami di bekuk sampai kami tidak berdaya dan tidak bisa bicara

Pada bait pertama ini, citraan yang ditemukan adalah citraan penglihatan. Terdapat pada larik lihat. kau adalah air kehidupan. Kata lihat menggambarkan indera mata yang dituangkan oleh penyair. Citraan perasaan pada bait pertama juga pada larik menambat hati bagi dunia dan selalu ingin kembali untuk mu. Larik menambat hati merupakan makna dari ketertarikan yang digambarkan oleh penyair. Kutipan bait puisi di atas penyair menggambarkan Danau Toba merupakan sumber kehidupan dan keindahannya memikat banyak mata ingin menikmati pesona Danau Toba. Penyair juga memberikan gambaran tentang Gunung Toba yang menakutkan seluruh dunia, namun sekarang Danau Toba menjadi harta yang paling berharga di Sumatera, pada bait puisi di atas penyair juga mengungkapkan rasa takut jika tanah leluhur tersebut di rampas. 
hey!! Tao toba. Sedikit saja kau bergetar dunia sudah takut.

percikkan keindahanmu kecantikkan mu bagi kaum ibu pertiwi, kegagahan, solid dan keberanian mu bagi raja raja batak tak tergoyah

Bait kedua puisi ini, ditemukan citraan penglihatan yang terdapat pada larik percikkan keindahanmu. Pada larik ini, penyair seolah-olah melihat keindahan yang ada pada Danau Toba. Keindahan umumnya diperuntukkan pada sesuatu yang kita lihat, sehingga kutipan tersebut dapat diklasifikasikan sebagai citraan penglihatan. Selain itu ditemukan juga citraan perasaaan yang terlihat pada kutipan berikut.

\author{
hey toba buka hati kami \\ generasi mu jangan tumpul hatinya \\ generasi mu bukan penjilat \\ generasi mu bukan konsumen \\ generasi mu adalah creator
}

Citraan perasaan yang dimaksud terdapat dalam larik hey toba buka hati kami. Larik tersebut menunjukkan tentang keinginan penyair untuk dekat dengan Danau Toba yang dituangkan penyair dari kata hati kami. Umumnya kata hati digunakan untuk menunjukan unsur perasaan.

\title{
4) Gaya Bahasa Figuratif (Majas)
}

Berikut analisis bahasa figuratif (majas) yang terdapat dalam Puisi Tao Toba karya Evi Sihite. Pada puisi ini, ditemukan empat majas yang menghiasi teks puisi, yakni antiklimaks, sarkasme, eskalamasio, dan polisidenton. Majas antiklimaks merupakan pemaparan pikiran atau hal secara berturut-turut dari yang lebih penting menurun kepada hal yang sederhana. Terdapat pada kutipan berikut,

\section{Generasi mu jangan tumpul hatinya \\ Generasi mu bukan penjilat \\ Generasi mu bukan konsumen \\ Generasi mu adalah creator}

Kutipan di atas merupakan majas antiklimaks karena mengungkapkan sebuah penegasan dimulai dari hal pentingnya, lalu dilanjutkan pada alasan-alasan dari penegasan pertama. Selanjutnya pada puisi tersebut ditemukan pula majas sarkasme yang merupakan gaya bahasa yang bersifat sindiran langsung dan kasar. Majas ini terdapat pada bait keempat baris pertama, yaitu pada larik anak anak gadis mu bukan pembantu budak arab dan Malaysia. Pada kata kutipan tersebut penyair bermaksud mengingatkan dengan kalimat sindirian yang tegas kepada para gadis-gadis suku Batak sebab diketahui gadis Batak memiliki keistimewahan yang berbeda. 
Selanjutnya ditemukan majas Ekskalamasio yang merupakan ungkapan dengan menggunakan kata-kata seru. Terlihat pada bait kelima, baris keenam yaitu pada larik generasimu punya prinsip!. Larik tersebut menunjukan penegasan penyair serta peringatan yang diintonasikan dengan nada yang sangat tegas. Pada larik puisi tersebut penyair memaparkan tentang anak-anak yang tinggal di sekitaran Danau Toba sudah memiliki pola pikir yang berkembang, yang diutakan penyair dengan kata punya prinsip. Selain itu ditemukan pula majas Polisindenton yang merupakan pengungkapan suatu kalimat atau wacana, dihubungkan dengan kata penghubung. Majas ini terdapat dalam bait keenam baris kelima yaitu larik lupakan sajak ini. Tapi ingat pesannya. Larik tersebut mengungkap penegasan penulis yang terdiri dari dua kalimat yang disatukan oleh kata penghubung.

\section{E. Kesimpulan}

Berdasarkan hasil penelitian dan analisis pembahasan, ketiga puisi pada Antologi Puisi Seribu Sajak Tao Toba akan disimpulkan dalam uraian berikut. Pertama, puisi berjudul Sebuah Kenangan Ziarah ke Atas Danau karya Paulus Simangunsong, berdasarkan kajian Stilistika terdapat dua jenis gaya diksi pada puisi tersebut yaitu diksi denotasi dan diksi konotasi. Gaya rima yang ditemukan pada puisi adalah rima patah dan rima terus. Gaya citraan yang ditemukan adalah citraan penglihatan, citraan perasaan, citraan pengecapan, citraan penciuman, dan citraan gerak. Untuk bahasa figuratif yang ditemukan dalam puisi adalah retoris, ekskalamasio, personifikasi, alegori, dan hiperbola. Kedua, puisi berjudul Tao Toba karya Evi Sihite, berdasarkan kajian aspek stilistika terdapat diksi denotasi dan diksi konotasi. Gaya rima yang ditemukan rima sejajar. Gaya citraan yang ditemukan pada puisi ini adalah citraan penglihatan dan citraan perasaan. Untuk bahasa figuratif yang ditemukan dalam puisi adalah antiklimaks, sarkasme, ekskalamasio, dan polisidenton.

Antologi puisi berjudul Seribu Sajak Tao Toba yang digagas oleh Jhon Fawer Siahaan, seorang penyair kelahiran Sumatera Utara ini, memuat puluhan puisi yang diciptakan oleh berbagai pernyair Sumatera Utara. Identitas kedaerahan begitu melekat pada teks puisi-puisi ini. Oleh sebab itu, banyak hal dalam ketatabahasaan yang mungkin terlupakan oleh seorang editor puisi. Kesalahan yang paling banyak ditemukan adalah kesalahan ejaan, yang menyangkut tanda baca, penulisan huruf kapital, penulisan huruf miring, huruf tebal, dan lainlain, Sesuai dengan fungsinya, peran seorang editor sangat besar bagi seorang penulis. Editor merupakan rekan penulis/penyair dalam dalam penerbitan buku. Tidak ada seorang penulis pun yang cipta karyanya sempurna meskipun sudah melakukan swasunting, maka peran seorang editor akan terus diperlukan selama karya tulis itu ada. Pada kesempatan yang baik ini, peneliti 
memberi saran kepada semua jenis tulisan/karya sastra yang akan dipublikasikan, sebaiknya konten tersebut berulang kali disunting oleh beberapa editor, agar kesan estetika pada karya sastra puisi, benar-benar tersampaikan dan dapat dinikmati oleh pembaca.

\section{DAFTAR PUSTAKA}

Daulay, Muhammad Anggie Januarsyah. 2013. Stilistika; Menyimak Gaya Kebahasaan Sastra. Jakarta: Halaman Moeka Publishing.

Eli Syarifah Aeni, M.Hum. 2016. Edit-Linguistik Mahir menyunting Naskah. Bandung: Media Cendekia Muslim.

Keraf, G. 1981. Diksi dan Gaya Bahasa. Ende Flores: Kanisius.

Kamus Besar Bahasa Indonesia. 2011. Jakarta; Gramedia Pustaka Utama.

Purba, Antilan. 2005. Stilistika Kaji Bahasa Karya Sastra. Medan: Fakultas Bahasa dan Seni Universitas Negeri Medan.

Ratna, Nyoman Kutha. 2009. Stilistika Kajian Puitika Bahasa, Sastra, dan Budaya. Yogyakarta: Pustaka Pelajar.

Siahaan, Jhon Fawer. 2014. Seribu Sajak Tao Toba. Medan: CV. Mitra.

Sudaryanto. 2003. Metode dan Aneka Tehnik Analisis Bahasa (Pengantar Penelitian Wahana Kebudayaan secara Linguistik). Yogyakarta: Duta Wacana University Press.

Tarigan, H. Guntur. 2011. Prinsip-prinsip Dasar Sastra. Bandung: Angkasa. 